НАУКОВИЙ ВІСНИК

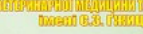

Sentific messenger of Lviv National University of

(x)

और औै

1 is 1 if



Том 22 № 92
Науковий вісник Дьвівського національного університету ветеринарної медицини та біотехнологій імені С.3. Гжицького. Серія: Сільськогосподарські науки

Scientific Messenger of Lviv National University of Veterinary Medicine and Biotechnologies. Series: Agricultural sciences

UDC 636.14.082:502.211(477,8)

\title{
Hutsul horse breed is an aboriginal breed of the Ukrainian Carpathians
}

\author{
L. F. Starodub ${ }^{1}$, Y. P. Stefurak ${ }^{2}$, I. V. Stefurak², I. M. Zelenchuk ${ }^{3}$, Y. I. Zelenchuk ${ }^{3}$, R. V. Wojcicki ${ }^{4}$ \\ ${ }^{1}$ Institute of Animal Breeding and Genetics nd. a. MV Zubets NAAS, Chubinskoe, Ukraine \\ ${ }^{2}$ Hutsulshchyna National Nature Park, Kosov, Ivano-Frankivsk region, Ukraine \\ ${ }^{3}$ Verkhovinskiy National Nature Park, Ivano-Frankivsk region, Verkhovyna district, p. Upper Yasenov, Ukraine \\ ${ }^{4}$ Local expert in the city of Sudova Vishnia in Lviv region, Ukraine
}

\section{Article info}

Received 24.02.2020

Received in revised form 25.03 .2020

Accepted 26.03.2020

Institute of Animal Breeding and Genetics nd. a. MV Zubets NAAS, Pogrebnyaka str., 1, Chubinskoe, Boryspil district, Kiev region, 08321, Ukraine.

Tel.: +38-097-459-34-88

E-mail: starodublf@gmail.com

Hutsulshchyna National Nature Park, Druzhby str., 84, Kosov, Ivano-Frankivsk region, 78600 Ukraine.

Verkhovinskiy National Nature Park, Ivano-Frankivsk region, Verkhovyna district, $p$. Upper Yasenov, 78712, Ukraine

Local expert in the city of Sudova Vishnia in Lviv region, 81340 , Ukraine.
Starodub, L. F., Stefurak, Y. P., Stefurak, I. V., Zelenchuk, I. M., Zelenchuk, Y. I., \& Wojcicki, R. $V$. (2020). Hutsul horse breed is an aboriginal breed of the Ukrainian Carpathians. Scientific Messenger of Lviv National University of Veterinary Medicine and Biotechnologies. Series: Agricultural sciences, 22(92), 119-124. doi: 10.32718/nvlvet-a9220

Hutsul horses are the oldest Ukrainian breed and belong to the local and endangered breeds of farm animals in Ukraine. The formation and preservation of the Hutsul horse breed took place in Ukrainian lands. Proof of this are built: the state factory stable in the village. Drohobych in the Lviv region in 1822, a horse-breeding station for Hutsul horses in the Luchina meadow in Southern Bukovina (1877), in the Galician Hutsul region two stables of Hutsul cucumbers: in Kosovo (1891) and in the village of Zhabye (1895). State Herd of Cucumbers in Sudova Vyshna (1907) in Lviv Region. Of the 6 genealogical lines of prominent Hutsul stallions, 3 ogres were born in the Ukrainian lands - Goral, Gurul and Polyan. Measures for the conservation and development of Hutsul horses are held in the Hutsul and Verkhovyna National Nature Parks in international cooperation within the framework of the Poland-Belarus-Ukraine crossborder cooperation program. Hutsulshchyna National Nature Park in 2015 took part in the project "Creation of the Polish-Ukrainian Center for Breeding and Promotion of Hutsul Breed Horses", and Verkhovynsky National Nature Park in 2020 takes part in the international Ukrainian-Polish project "Knowledge of Nature and Wealth Carpathians with a Hutsul horse". According to the State Breeding Register 2011-2017, in Ukraine there is an annual reduction in the number of breeding farms, the total and breeding stock of Hutsul horses. Today, only 2 farms (NGO "Plemkonecentr" and FG "Polonynske farm") for breeding Hutsul horses have the status of breeders. According to calculations, in accordance with the FAO recommendations, these animals are at critical risk status, and according to the assessment system of the European Livestock Association, Hutsul horse breed is at high risk of losing the gene pool of the breed. To preserve the Hutsul horse breed, the joint cooperation of owners (breeding and private farms) of purebred and the most typical herd of Hutsul horses, scientists and specialists is necessary.

Key words: hutsul horse, aboriginal breed, history of horse breeding, risk status of Hutsul breed.

\section{Гуцульська порода коней - аборигенна порода українських Карпат}

\author{
Л. Ф. Стародуб ${ }^{1}$, Ю. П. Стефурак ${ }^{2}$, І. В. Стефурак ${ }^{2}$, І. М. Зеленчук ${ }^{3}$, Я. І. Зеленчук ${ }^{3}$ Р. В. Войціцький ${ }^{4}$ \\ ${ }^{1}$ Інститут розведення і генетики тварин імені М.В. Зубияя НААН, с. Чубинське, Київська область, Украӥна \\ ${ }^{2}$ Національний природний парк “Гуцульщзин”, Косів, Івано-Франківська область, Украйна \\ ${ }^{3}$ Природний національний парк “Верховинський”, с. Верхній Ясенів, Івано-Франківська область, Украӥна \\ ${ }^{4}$ Краєзнавець, м. Судова Вишня, Львівська область, Украӥна
}

Гуиульські коні є найстарішою украӥнською породою і належать до локальних та зникаючих порід сільськогосподарських тварин в Україні. Формування та збереження породи гуцульських коней відбувалося на украӥнських землях. Доказом изого є побудовані: державна заводська конюшня в с. Дроговиж на Львівщчині у 1822 році, станція конярства расових гуиульських коней на полонині Лучині в Південній Буковині (1877р.), у Галицькій Гуцульщуині дві стайні гуцульських огирів: у Косові (1891 р.) та в селищі Жаб’є 
(1895 р.), Державна стаднина огирів у Судовій Вишні (1907 р.) на Львівщчині. Із 6 генеалогічних ліній видатних жеребиів-плідників гуиульської породи 3 огирі народжені на украӥнських землях - Горал, Гурул та Полян. Заходи шодо збереження та розвитку коней гуиульської породи проводяться в Національних природних парках “Гуцульщина” та “Верховинський” у міжнародній співпраці в рамках програми транскордонного співробітництва Польщза-Білорусь-Україна. Національний природний парк “Гуиульщина” в 2015 роиі взяв участь в проекті “Створення Польсько-Українського иентру розведення та популяризації коней гуиульської породи”, а Національний природний парк “Верховинський” у 2020 рочі бере участь у міжнародному украӥнсько-польському проекті “Пізнання природи і багатства Карпат з гуиульським конем”. За даними Державного племінного реєстру $2011-2017$ років, в Украӥні спостерігається щорічне скорочення кількості племінних господарств, загального й маточного поголів 'я коней гуцульської породи. На сьогодні тільки 2 господарства (НВА “Племконецентр” та ФГ “Полонинське господарство”) з розведення гуиульської породи коней мають статус племрепродуктора. За проведеними розрахунками, відповідно до рекомендацій FАО, ці тварини перебувають за статусом ризику в критичному стані, а за системою оиінки Свропейської асоиіачії з тваринництва, гуиульська порода коней перебуває в сильній небезпеці втрати генофонду породи. Для збереження гуцульської породи коней необхідна об'єднана співпрачя власників (племінні та приватні господарства) чистопородного і найбільш типового поголів'я гуиульських коней, науковиів та фахівиів.

Ключові слова: гуцульський кінь, аборигенна порода, історія конярства, статус ризику гуцульської породи.

\section{Ветуп}

Відносна кількість коней в нашій країні складає близько 3\% серед усієї різновидності домашніх ссавців. За останні десятиріччя в Україні задокументовано племінне розведення 17 порід коней, яких поділяють на групи за переважним використанням і походженням (Guzyev, 2012). Гуцульські коні є найстарішою українською породою (Golovach \& Golovach, 2013), сформованою понад 400 років тому (Gibala, 2017) на просторах гірської частини Українських Карпат Гуцульщини. Незамінні у всіх сферах життєдіяльності місцевих жителів у минулому, ці коні й досі залишаються надійними помічниками при різному використанні в складних кліматичних та географічних умовах. Збереження генофонду гуцульської породи коней, удосконалення іiі племінних та господарських якостей були включені в "Програму збереження генофонду локальних і зникаючих порід сільськогосподарських тварин в Україні на 2017-2025 роки”. За даними Державного племінного реєстру, зробленого в динаміці 2011-2017 років, спостерігається тенденція до щорічного скорочення кількості як племінних господарств, так і загального й маточного поголів'я коней гуцульської породи. За проведеними розрахунками, відповідно до рекомендацій FAO, ці тварини перебувають за статусом ризику в критичному стані (Boettcher et al., 2011). За іншою системою оцінки згідно 3 рекомендаціями Європейської асоціації 3 тваринництва, що розраховується за показниками рівня інбридингу протягом 50 років відтворення $(\Delta \mathrm{F}$ $50)$, гуцульська порода коней перебуває в сильній небезпеці втрати генофонду породи. Розрахований рівень статусу ризику, в яких перебуває порода, надає інформацію для зацікавлених осіб (насамперед відповідним державним структурам) про те, де і як швидко необхідно вживати відповідні дії (Gladij et al., 2018).

Питання вивчення особливостей породи гуцульського коня, іiі історії розвитку та збереження є досить актуальним на сьогодні для подальшого сприяння захисту унікальних гірських коней та збільшення їхньої чисельності. Тому метою нашої роботи було проведення ретроспективного аналізу літературних даних історії розведення та збереження гуцульських коней на українських землях, починаючи з XIX століття та висвітлення системи заходів збереження коней гуцульської породи в теперішній час.

\section{Матеріал і методи досліджень}

Для вивчення історії розведення та збереження гуцульських коней на українських землях, починаючи 3 XIX століття, був проведений ретроспективний аналіз літературних даних, фотографій і листівок XIX$\mathrm{XX}$ ст. із сімей колишніх наїзників та працівників Державної стаднини огирів (станція жеребців) у Судовій Вишні. Матеріали із сімей колишніх наїзників та працівників Державної стаднини огирів у Судовій Вишні були надані їх родичами, які проживають у Польщі, та зібрані краєзнавцем Войціцьким Романом Володимировичем із містечка Судова Вишня, що на Львівщині. Висвітлення системи заходів збереження коней гуцульської породи в теперішній час було проведено на основі матеріалів, наданих співробітниками Національного природного парку “Верховинський” та Національного природного парку "Гуцульщина".

\section{Результати та їх обговорення}

Аналіз архівних матеріалів та літературних даних про розведення та збереження гуцульських коней на українських землях, починаючи 3 XIX ст., свідчить про те, що гуцульські коні - це найстаріша українська порода коней, які отримали назву від українських горян. Гуцульських коней було виведено на території Східних або Лісистих Карпат в районі Гуцульщини і Буковини в верхніх течіях рік Черемоша, Прута і Путили. Остаточно не встановлено, як виникла ця порода. Існує думка про походження гуцульського коня від примітивних коней, таких як тарпан і кінь Пржевальського, у поєднанні з благородними арабськими, польськими, турецькими, норицькими кіньми, загартованими гірською природою (Gibala, 2017). Основним ареалом поширення гуцульського коня була територія українських Карпат. Отже, порода гуцульських коней формувалася у сім'ях українських гуцулів, а вже потім була вдосконалена австрійськими, польськими та румунськими конярами (Golovach \& Golovach, 2013; Romanenko, 2018). У кінці XIX - на початку XX ст. територія Буковинської Гуцульщини була найбільшим осередком гуцульського конярства. На полонині Лучині, в Південній Буковині, розташовувалася станція конярства расових гуцульських коней (1877 р.). Основоположником конярства на Лучи- 
ні був гуцул-коняр Ревенчук із села МолдавиціСулиці. Йому вдалося знайти серед коней-гуцулів 10 кобил і одного огира чисто гуцульської раси. Їхня кількість невдовзі зросла до тисячі. У Галицькій Гуцульщині австрійський уряд тримав дві стайні гуцульських огирів: у Косові, засновану в 1891 році, та в селищі Жаб'є, створену в 1895 році (Senkiv, 2014). Доказом формування гуцульського коня на українських землях є побудована державна заводська конюшня в с. Дроговиж на Львівщині у 1822 році, яка згодом була переведена у Судову Вишню (містечко Мостиського району Львівської області). У 1907 році в Судовій Вишні почалося будівництво Державної Стаднини (станціï) огирів (рис. 1) (Gazeta Lwowska, 1909).

За короткий час збудували три конюшні на 150 коней, стайню-лікарню для хворих коней, велику криту школу верхової їзд, каретний двір, кузню (рис. 2, 3) (Pocztówka, 1908, Pocztówka, 1909).

3 кінця ХІХ до початку XX ст. жеребців із Судової Вишні перевозили до пунктів розмноження (тоді в Австрії їх називали “Кінські підстанції') в Коломию, Львів, Косів, Станіслав, Перемишль, де розміщувалася австрійська кіннота та підрозділи, де були коні для офіцерів у піхотних, артилерійських та саперних частинах.

До Другої світової війни Державна стаднина огирів обслуговувала військові частини та приватних власників коней у воєводствах Львівському, Тернопільському та Станіславському (табл. 1) (Korbel, 1933).

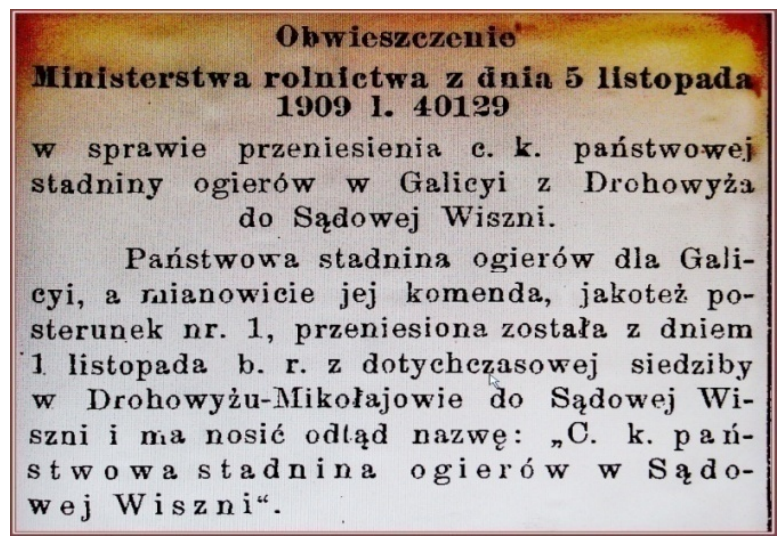

Рис. 1. Розпорядження про перенесення Державної стаднини огирів з Дроговижа до Судової Вишні

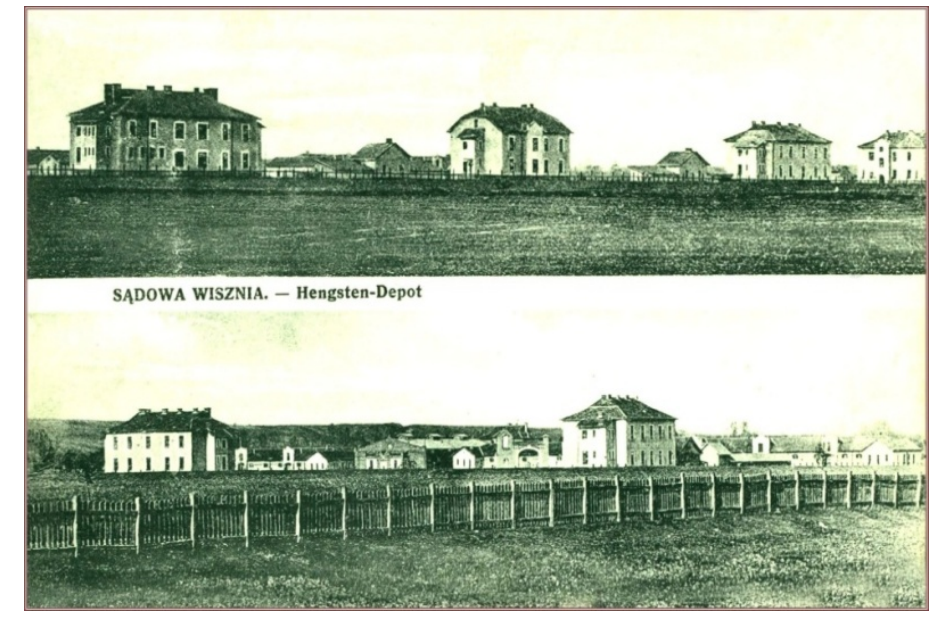

Рис. 2. Побудована та огороджена Державна стаднина огирів у м. Судовій Вишні, 1908 р.

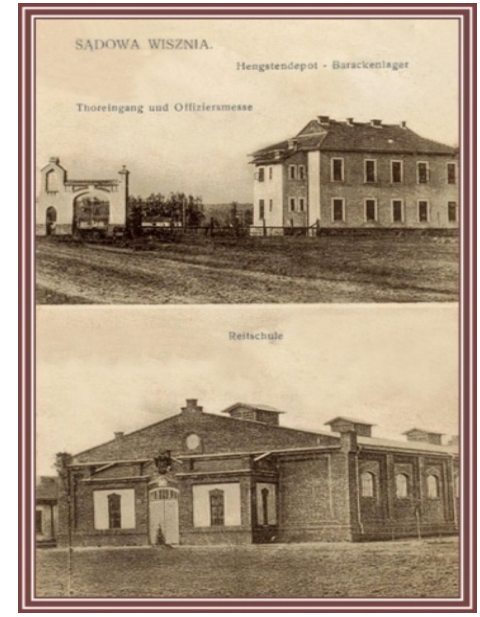

Рис. 3. Головна брама. Школа верхової їзди, 1909 р.

\section{Таблиця 1}

Місцевість, де використовувалися жеребці гуцульської породи з Державної стаднини огирів

\begin{tabular}{lc}
\hline \multicolumn{1}{c}{ Повіт, місцевість } & Порода коней \\
\hline Бучацький повіт, місто Бучач & гуцульська \\
місто Яворів & арабо-гуцульська \\
Станіславський повіт, село Павелче & гуцульська \\
Мостиський повіт, село Ружники & гуцуло-коник \\
Мостиський повіт, містечко Судова & гуцульська, гуцу- \\
Вишня & ло-коник \\
Гміна Жаб’є & гуцульська \\
\hline
\end{tabular}

Всіх разом у Судовій Вишні в 1933 році було 144 голів коней, в тому числі й жеребці гуцульської породи (табл. 2) (Korbel, 1933).

\section{Таблиця 2}

Клички жеребців гуцульської породи та їх помісей, які в 1933 році перебували в Державній стаднині огирів

\begin{tabular}{ccc}
\hline Порода & Кличка & $\begin{array}{c}\text { Кількість } \\
\text { голів }\end{array}$ \\
\hline Гуцульська & $\begin{array}{c}\text { Burek, Dudziarz, Fuks, } \\
\text { Góral-9, Góral-4, Góral- } \\
\text { 12, Hroby-I, Hroby-4, } \\
\text { Kapitan, Pryslip }\end{array}$ & 10 \\
$\begin{array}{c}\text { Арабо-гуцульські } \\
\text { помісні } \\
\begin{array}{c}\text { Гуцуло-коник } \\
\text { помісні }\end{array}\end{array}$ & Capul-15 & 1 \\
\hline
\end{tabular}

Існує 6 генеалогічних ліній видатних жеребцівплідників гуцульської породи, які визнані в країнах, де розводять цих коней. 3 них три огирі народжені на українських землях (Горал, народжений в 1899 р. в околицях селища Жаб’є, Гургул - в 1924 р. та Полян - 
в 1929 р., народжені в Косівському повіті), а три інших - Гробі, народжений в 1895 р., Оусор - в 1929 р., Петросу - в 1930 р. в Румунії (Golovach \& Golovach, 2013).

Дані ретроспективного аналізу архівних та літературних матеріалів свідчать про те, що формування та збереження породи гуцульських коней відбувалося на українських землях.

Заходи щодо збереження та розвитку коней гуцульської породи проводяться і зараз. Так, у національному природному парку (НПП) “Гуцульщина" на відповідному рівні проводиться науково-дослідна робота, спрямована на збереження генофонду гуцульської породи коней, а також своїми силами вже роз- почато створення центру з відтворення гуцульських коней та гіпотерапії - формується селекційне стадо. Метою діяльності Центру стане забезпечення основних напрямків ведення племінного, виробничого, спортивного, рекреаційного, продуктивноприкладного конярства. Гуцульський кінь повинен стати своєрідним символом парку і зображеннямлоготипом на сувенірній продукції НПП. Зараз у НПП "Гуцульщина" є 12 голів племінних гуцульських коней. Чистопородного жеребця 52 Варніка 255 лінії Оусора, завезеного з Польщі, використовують за обміном як плідника в Закарпатській та Житомирській областях (рис. 4).

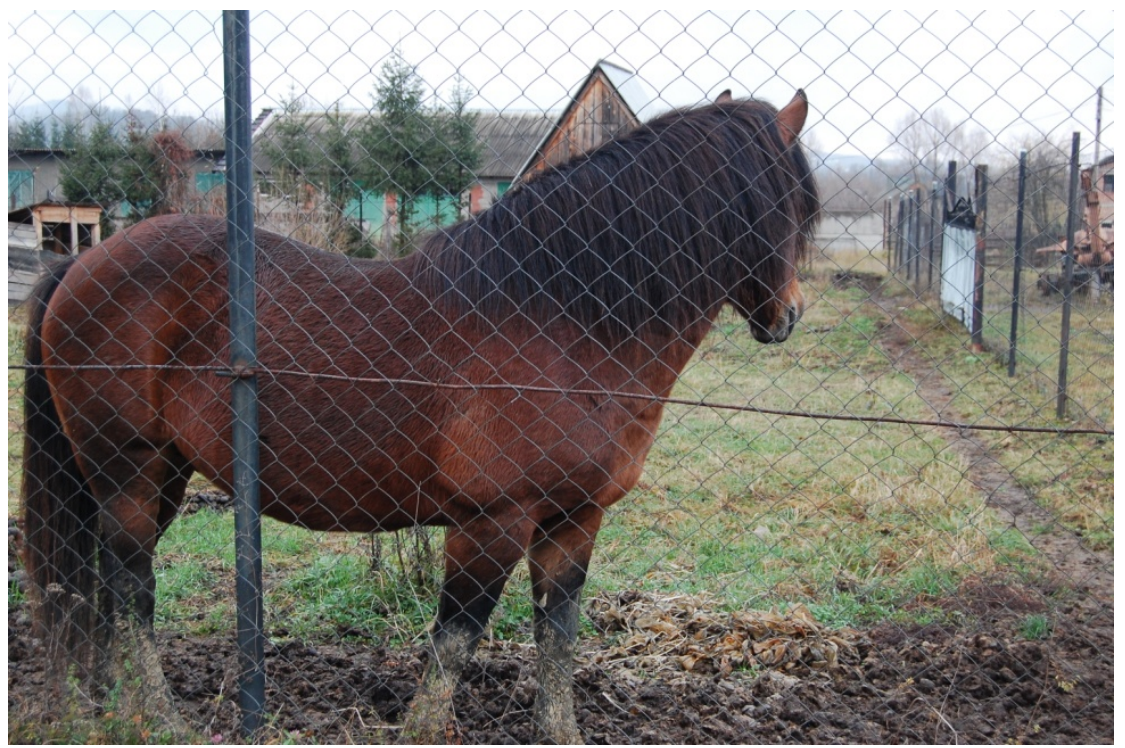

Рис. 4. Чистопородний плідник 52 Варнік 255 гуцульської породи. Національний природний парк "Гуцульщина"

В напрямку збереження гуцульської породи коней в Карпатському регіоні досить актуальним є міжнародне співробітництво в рамках програми транскордонного співробітництва Польща-Білорусь-Україна. Так, Національний природний парк "Гуцульщина" в 2015 році взяв участь в проекті “Створення ПольськоУкраїнського центру розведення та популяризації коней гуцульської породи". Спільно 3 польськими партнерами було розроблено стратегію "Повернення гуцульського коня в його природне середовище”. А Національний природний парк "Верховинський" у 2020 році бере участь у міжнародному українськопольському проекті “Пізнання природи i багатства Карпат з гуцульським конем”.

На Гуцульщині та Закарпатті до цього часу дотримуються давньої традиції проведення виставокоглядів коней, які ще з 1925 року за ініціативи спілки конярів почали проводити спочатку в Жаб’є, а потім у Косові та Устеріках (Romanenko, 2018). Дані про проведення однієї з виставок коней у НПП “Верховинсь- кий”: в урочищі Запідок на околицях Верхнього Ясенова 28 гривастих особин із Криворівні, Буківця, Верхнього Ясенова, Верховини та Яворова змагалися за право бути кращими. Виставка проводилася 3 метою популяризації аборигенної породи гуцульських коней та переваги їх використання в рекреаційнотуристичній галузі. Власне, акція відбулася за сприяння Свропейського Союзу в рамках семінарунавчання "Гуцульський кінь в культурі Карпат" (рис. 5).

Однак за останні роки через кризові явища в економіці України, суттєве зменшення державної фінансової підтримки галузі конярства племрепродуктори 3 розведення гуцульської породи коней в Україні опинились в скрутному економічному стані. На сьогодні в Україні тільки 2 господарства (НВА “Племконецентр" та ФГ “Полонинське господарство”) 3 розведення гуцульської породи коней мають статус племрепродуктора. Племінне поголів'я гуцульської породи коней різко зменшилося (табл. 5). 


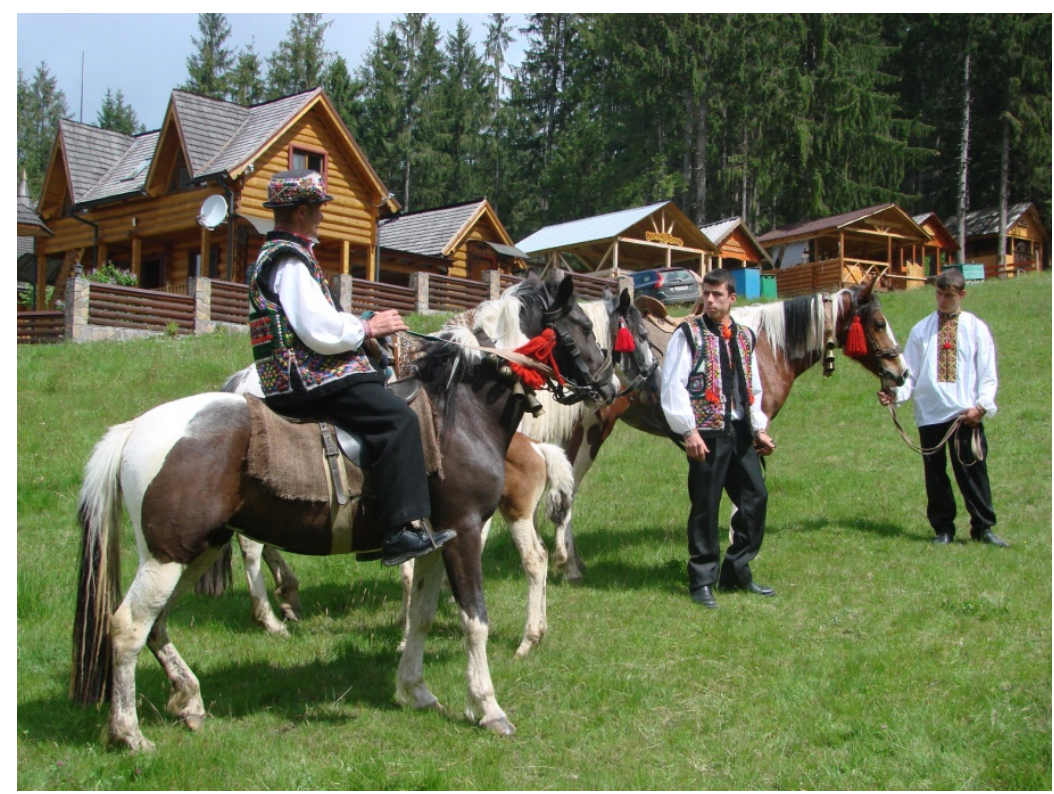

Рис. 5. Виставка-огляд коней гуцульської породи.

Національний природний парк "Верховинський”

Таблиця 3

Наявність племінного поголів’я гуцульської породи коней (гол.), станом на 01.01.2020 р.

\begin{tabular}{|c|c|c|c|c|c|}
\hline Область & Господарство & Жеребці & Кобили & $\begin{array}{l}\text { Ремонтний } \\
\text { молодняк }\end{array}$ & Реєстр \\
\hline \multirow[b]{2}{*}{ Закарпатська } & НВА “Племконецентр” & 3 & 30 & 2 & \multirow{4}{*}{$\begin{array}{l}\text { З Державного реєстру суб’єктів } \\
\text { племінної справи у тваринництві } \\
\text { За даними інвентаризації пого- } \\
\text { лів'я НПП “Гуцульщина” } \\
\text { За даними інвентаризації пого- } \\
\text { лів’я НПП “Верховинський” }\end{array}$} \\
\hline & ФГ “Полонинське господарство" & 2 & 22 & 56 & \\
\hline \multirow{2}{*}{$\begin{array}{l}\text { Івано- } \\
\text { Франківська }\end{array}$} & $\begin{array}{l}\text { Національний природний парк } \\
\text { "Гуцульщина" }\end{array}$ & 2 & 5 & 5 & \\
\hline & $\begin{array}{l}\text { Національний природний парк } \\
\text { "Верховинський” }\end{array}$ & - & 4 & 2 & \\
\hline
\end{tabular}

Складна ситуація склалася також в конярстві селянських господарств, які останні 25 років були основним суб'єктом $з$ розведення гуцульських коней і за-

лишаться таким надалі. Селекційно-племінна робота в цих господарствах проводиться стихійно або не проводиться зовсім (табл. 4).

\section{Таблиця 4}

Поголів’я типових гуцульських коней у селянських господарствах Львівської, Івано-Франківської та Закарпатської областей станом на 01.01.2020 p.

\begin{tabular}{cccc}
\hline Область & $\begin{array}{c}\text { Всього коней у селянсь- } \\
\text { ких господарствах }\end{array}$ & $\begin{array}{c}\text { Коні гуцульської } \\
\text { породи }\end{array}$ & Реєстр \\
\hline Закарпатська & 3000 гол. & $10-20 \%$ & $\begin{array}{c}\text { Держспоживслужба } \\
\text { ідентифікації тварин }\end{array}$ \\
Івано-Франківська & 7484 гол. & $10-20 \%$ & За даними статистичної форми 6- \\
сільрада (річна)
\end{tabular}

Отже, для збереження унікальної гуцульської породи коней сьогодні виникла необхідність об'єднати власників (племінні та приватні господарства) чистопородного і найбільш типового поголів'я гуцульських коней, а також науковців і фахівців 3 метою поліпшення селекційно-племінної роботи, застосування економічно-ефективних методів вирощування, годівлі, утримання та використання, впровадження наукових розробок для поліпшення господарсько-корисних та племінних якостей коней, а також налагодження міжнародної співпраці.

\section{Висновки}

Дані ретроспективного аналізу архівних та літературних матеріалів свідчать про те, що формування породи гуцульських коней в XIX-XX ст. відбувалося на українських землях.

В напрямку збереження гуцульської породи коней досить актуальним $є$ міжнародна співпраця в рамках програми транскордонного співробітництва ПольщаБілорусь-Україна. 
Починаючи з 2011 року, спостерігається тенденція до щорічного скорочення кількості як племінних господарств, так і загального й маточного поголів'я коней гуцульської породи.

Для збереження унікальної гуцульської породи коней необхідна об'єднана співпраця власників (племінні та приватні господарства) чистопородного i найбільш типового поголів'я гуцульських коней, а також науковців та фахівців.

\section{References}

Boettcher, P., Gandini, G., Martin, J. F., Joshi, B. K., Oldenbroek, K., \& Sponenberd, P. (2011). FAO Guidelines for the Vivo Conservation of Animal Genetic Resources (Draft). Roma: FAO.

Gladij, M. V., Polupan, Yu. P., Basovs`ky`j, D. M., Vy`shnevs`ky`j, L. V., Kovtun, S. I., \& Sy`dorenko, O. V. (2018) Programa zberezhennya genofondu lokalny`x i zny`kayuchy`x porid sil`s`kogospodars`ky`x tvary`n v Ukrayini na 20172025 roky`. Sumy: Sums`ky`j nacional’ny`j agrarny`j universy`tet (in Ukrainian).
Gibala, M. (2017). Koni guczulskoyi porody. Istoriya porody: http://www.huculy-polska-ukraina.eu/uk/ hucul_hist_uk.html (in Ukrainian).

Golovach, M. J., \& Golovach, M. M. (2013). Derzhavna knyga pleminnyx konej guczulskoyi porody. Tom II. Uzhgorod: Karpaty (in Ukrainian).

Guzyev, I. V. (2012). Metodologiya zberezhennya bioriznomanittya genetychnyx resursiv tvarynnycztva Ukrayiny' [dysertaciya]. Chubynske Kyivskoyi obl.: IRGT NAAN (in Ukrainian).

Korbel, T. (1933). Ogiery reproduktory. Panstwowych Zakladow Chowu Koni. Wydawnictwo Ministerstwa Polnictwa i Reform Polnych.

Pocztówka, wysłana ze Sądowej Wiszni do Wiednia 1908 roku. Na ten czas, wszystko już było zbudowano i ogrodzono:[ zdjęciu: 1].

Pocztówka z około 1909 roku. Brama Główna i Kantyna, oraz kryta ujeżdżalnia: [zdjęciu: 2].

Senkiv, I. (2014). Guczulska spadshhyna. Verxovyna: Guczulshhyna (in Ukrainian).

Romanenko, G. V. (2018). Historical aspects of breeding and preservation of Hutsul horse breed on the Ukrainian territory of the interwar Poland. Grani, 21(9), 81-89. doi: 10.15421/1718118. 